\title{
Sub-second calcium coupling between outside medium and subplasmalemmal stores during overstimulation/depolarisation-induced ciliary beat reversal in Paramecium cells
}

\author{
Helmut Plattner*, Stefanie Diehl, Marc R. Husser, Joachim Hentschel \\ Department of Biology, University of Konstanz, P.O. Box 5560, 78457 Konstanz, Germany
}

Received 19 December 2005; received in revised form 17 January 2006; accepted 30 January 2006

Available online 9 March 2006

\begin{abstract}
As amply documented by electrophysiology, depolarisation in Paramecium induces a $\mathrm{Ca}^{2+}$ influx selectively via ciliary voltage-dependent $\mathrm{Ca}^{2+}$-channels, thus inducing ciliary beat reversal. Subsequent downregulation of ciliary $\mathrm{Ca}^{2+}$ has remained enigmatic. We now analysed this aspect, eventually under overstimulation conditions, by quenched-flow/cryofixation, combined with electron microscope X-ray microanalysis which registers total calcium concentrations, [Ca]. This allows to follow Ca-signals within a time period ( $\geq 30 \mathrm{~ms})$ smaller than one ciliary beat ( $\sim 50 \mathrm{~ms}$ ) and beyond. Particularly under overstimulation conditions $\left(\sim 10^{-5} \mathrm{M} \mathrm{Ca}^{2+}\right.$ before, $0.5 \mathrm{mM} \mathrm{Ca}{ }^{2+}$ during stimulation) we find in cilia a [Ca] peak at $\sim 80 \mathrm{~ms}$ and its decay to near-basal levels within $110 \mathrm{~ms}(90 \%)$ to $170 \mathrm{~ms}$ (100\% decay). This [Ca] wave is followed, with little delay, by a [Ca] wave into subplasmalemmal Ca-stores (alveolar sacs), culminating at $\sim 100 \mathrm{~ms}$, with a decay to original levels within $170 \mathrm{~ms}$. Also with little delay [Ca] slightly increases in the cytoplasm below. This implies rapid dissipation of $\mathrm{Ca}^{2+}$ through the ciliary basis, paralleled by a rapid, transient uptake by, and release from cortical stores, suggesting fast exchange mechanisms to be analysed as yet. This novel type of coupling may be relevant for some phenomena described for other cells.
\end{abstract}

Keywords: $\mathrm{Ca}^{2+}$; Subplasmalemmal stores; Calcium stores; Cilia; Paramecium

\section{Introduction}

$\mathrm{Ca}^{2+}$-transients govern a variety of cellular phenomena, some occurring on a sub-second time scale [1-3], by different mechanisms for $\mathrm{Ca}^{2+}$ mobilisation and subsequent re-establishment of $\mathrm{Ca}^{2+}$ homeostasis [4-6]. In ciliated protozoans, specifically in Paramecium, $\mathrm{Ca}^{2+}$ regulates dense-core secretory vesicle (trichocyst) exocytosis $[7,8]$ and ciliary beat [9-11], notably depolarisation-induced ciliary beat reversal [12,13], among other phenomena [14]. Ciliary reversal parallels electrically or chemically induced depolarisation, causing activation of voltage-dependent $\mathrm{Ca}^{2+}$-channels which subsequently are rapidly inactivated by the very same $\mathrm{Ca}^{2+}$ [15]. In Paramecium, depolarisation-induced $\mathrm{Ca}^{2+}$-currents

\footnotetext{
* Corresponding author. Tel.: +49 753188 2228; fax: +49 7531882245 . E-mail address: helmut.plattner@uni-konstanz.de (H. Plattner).
}

may last only several milliseconds, e.g., during short depolarisation pulses [16]. Remarkably, this phenomenon of $\mathrm{Ca}^{2+}$ channel inactivation by an increase of intracellular $\mathrm{Ca}^{2+}$ concentration, $\left[\mathrm{Ca}^{2+}\right]_{i}$, has been recognised, though considerably later, in some neurons [17-19]. In both systems it may help to reduce the $\mathrm{Ca}^{2+}$ signal to the minimum required for cell activation. Moreover, in Paramecium, voltage-dependent $\mathrm{Ca}^{2+}$-channels are localised exclusively in the ciliary membranes [20]. All this may help to restrict the $\mathrm{Ca}^{2+}$-signal in cilia during depolarisation and, thus, contribute to optimise energetic requirements for re-establishment of $\left[\mathrm{Ca}^{2+}\right]_{i}$ homeostasis.

How $\mathrm{Ca}^{2+}$ in cilia of Paramecium - or any comparable system - is downregulated after activation has not been analysed so far. Plausible assumptions would be, e.g., inactivation by binding to $\mathrm{Ca}^{2+}$-binding proteins [14], including calmodulin [21] and some other functional target molecules, and/or 
diffusion to the ciliary basis and then into the nearby cortical cytosol for subsequent elimination. This may be particularly important when $\mathrm{Ca}^{2+}$ influx goes on for longer periods of time, for instance when Paramecium cells are exposed to depolarising solutions [22].

Two types of $\mathrm{Ca}^{2+}$-pumps $\left(\mathrm{Ca}^{2+}\right.$-ATPases) have been found in Paramecium, a plasmalemmal type activated by $\mathrm{Ca}^{2+} /$ calmodulin [23] and a SERCA-type occurring in alveolar sacs [24,25], the established cortical Ca-stores of Paramecium [26-30]. The presence of a $\mathrm{Ca}^{2+}$-ATPase (pump) in ciliary membranes has been denied [23]. So far, there was also no evidence of any role for alveolar sacs in ciliary activity regulation. These sacs line the entire surface of Paramecium (and of any other pathogenic or harmless member of the phylum Alveolata), with the exception of trichocyst docking sites and the emergence site of cilia.

Any analysis of $\mathrm{Ca}^{2+}$-dynamics in cilia by fluorochromes, particularly over short times, remains problematic. As an alternative, we have previously established a quenchedflow/cryofixation procedure appropriate to achieve timedependent cell stimulation [31] and retention of calcium in place [27] for subsequent analysis by electron microscopic (EM) energy-dispersive X-ray microanalysis, EDX [29,30]. EDX allows to measure locally total calcium concentrations, $[\mathrm{Ca}]$, by recording the main element-specific peak, $\mathrm{Ca} \mathrm{K} \alpha$, with high spatial and temporal resolution. In our case this is possible from $30 \mathrm{~ms}$ on, the dead-time of the quenched-flow machine where depolarisation can be induced by rapid mixing cells with high $\left[\mathrm{K}^{+}\right]$medium. With an electron probe of $\sim 63 \mathrm{~nm}$, in the EM operated in the scanning transmission mode, STEM, [Ca] can be conveniently registered in cilia of $\sim 300 \mathrm{~nm}$ diameter as well as in alveolar sacs (average width $\sim 100 \mathrm{~nm}$ ), but not in the $15 \mathrm{~nm}$ wide subplasmalemmal space between these sacs and the plasma membrane.

In brief, using this methodology we now find, under overstimulation conditions (see Section 2), a rapid increase of $[\mathrm{Ca}]$ in cilia, culminating within the second stroke and decaying with the third stroke after stimulation. Quite unexpectedly we then see a rapid [Ca] increase in alveolar sacs within the same time range, paralleled by $\mathrm{Ca}^{2+}$ dissipation into the nearby cytosol. These novel findings will also be interesting in the context of current problems concerning the crosstalk between cortical stores and the outside medium via the cell membrane in a variety of cell types.

\section{Materials and methods}

\subsection{Cells}

Paramecium tetraurelia wildtype strain $7 S$ and, for controls, strain $d 4-500 r$ were cultivated as indicated previously [30]. Strain $d 4-500 r$ contains no functional $\mathrm{Ca}^{2+}$-influx channels in its cilia [32]. Before each experiment, performance of ciliary beat reversal upon adding $\mathrm{KCl}$ (to yield a final con- centration of $20 \mathrm{mM}$ ) was tested, as well as its absence in d4-500r cells.

\subsection{Stimulation conditions and quenched-flow/freeze-substitution}

Under "standard conditions" $7 S$ cells were contained in the medium specified previously [29,30], including Pipes buffer (pH 7.2), with $\mathrm{CaCl}_{2}$ and $\mathrm{KCl}$ added, $1 \mathrm{mM}$ each. To achieve a higher extra- to intracellular gradient, $\left[\mathrm{Ca}^{2+}\right]_{\mathrm{o}} /\left[\mathrm{Ca}^{2+}\right]_{\mathrm{i}}$, $\left[\mathrm{Ca}^{2+}\right]_{\mathrm{o}}$ was eventually reduced to $\sim 10^{-5} \mathrm{M}$ for $\sim 75 \mathrm{~min}$ before stimulation, and $\left[\mathrm{Ca}^{2+}\right]_{\mathrm{o}}$ was increased together with $\mathrm{KCl}$ selectively during stimulation by rapid mixing to yield $0.5 \mathrm{mM} \mathrm{CaCl}_{2}$ and $20 \mathrm{mM} \mathrm{KCl}$ (final concentrations seen by the cells), respectively. This is designated furtheron as "overstimulation". The mutant, $d 4-500 r$, was processed under "standard conditions", yet with $\left[\mathrm{Ca}^{2+}\right]_{\mathrm{o}}=10 \mathrm{mM}$ to intensify any potential $\mathrm{Ca}^{2+}$ signal (if any). The corresponding details are indicated in the respective figure captions. For controls ( $0 \mathrm{~ms}$ data points), cells were mixed for $80 \mathrm{~ms}$ with the same solution in which they were before the respective stimulation experiments. Rapid mixing was performed in the quenchedflow apparatus previously described [31].

Retention of calcium in samples, with the exclusion of any detectable redistribution during freeze-substitution, was achieved by the method previously described in detail $[27,29,30]$.

\subsection{EDX analysis and statistics}

Analyses were conducted in a Zeiss/Leo EM912 Omega electron microscope equipped with a scanning transmission (STEM) unit, type DSA unit STEM digital attachment, and an energy-dispersive X-ray microanalysis unit, type INCA from Oxford Instruments. Sections (500 nm thick) were analysed in the EM, operated in the scanning transmission mode (STEM) at $80 \mathrm{kV}$ acceleration voltage, $\sim 12 \mu \mathrm{A}$ beam current and a spot size adjusted to $63 \mathrm{~nm}$. Net $\mathrm{Ca} \mathrm{K} \alpha$ counts were registered by spot measurements, e.g., in $0.5 \mu \mathrm{m}$ intervals along longitudinally cut cilia, in strictly cross-cut alveolar sacs, over longitudinally cut ciliary basal bodies (containing also closely surrounding alveolar sacs), in the cytosol at a distance of 0.5 and $1.0 \mu \mathrm{m}$, respectively, from ciliary bases, and in cortical mitochondria. Measurements in alveolar sacs were randomised irrespective of the location relative to cilia which is feasible considering the rapid spread of $\mathrm{Ca}^{2+}$ inside stores [33]. [Ca] in alveolar sacs of unstimulated cells, previously estimated as $\sim 43 \mathrm{mM}$ [29], can serve as an internal reference value. An example of positions analysed is shown in Fig. 1. Statistical analysis was performed by paired Student's $t$-test for the data set obtained under "standard" stimulation conditions, but no significant differences within the time course in a given compartment were found. For "overstimulated" samples, to achieve higher accuracy, we applied the SigmaStat 2.03 program (Jandel Scientific, San Rafael, CA). 


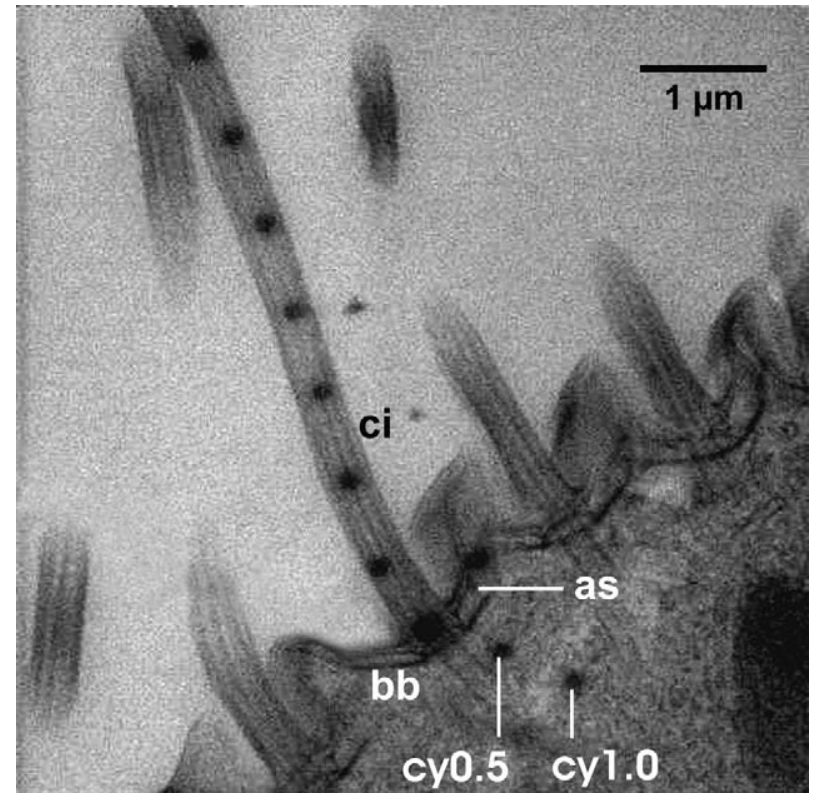

Fig. 1. STEM image of a semi-thin section used for EDX analysis, with positions of point measurements visible as contamination spots over a cilium (ci), alveolar sac (as) and a ciliary basal body (bb), as well as in cytoplasmic domains at 0.5 and $1.0 \mu \mathrm{m}$ distance (cy 0.5, cy 1.0$)$, respectively, from a ciliary basal body. Scale bar $=0.5 \mu \mathrm{m}$.

\section{Results}

Fig. 1 gives an example of how $500 \mathrm{~nm}$-thick sections were analysed by STEM/EDX, with data acquisition points labelled by contamination spots formed during analysis. The probe diameter of $63 \mathrm{~nm}$, with a calculated top/bottom spread to $72 \mathrm{~nm}[29]$ is smaller than any of the structural details analysed, including cilia ( $\sim 300 \mathrm{~nm}$ diameter) and alveolar sacs with an average width of $98 \pm 11 \mathrm{~nm}$ [30]. Data collected over ciliary basal bodies include counts from closely surrounding alveolar sacs whose volume contribution is estimated as $\sim 30 \%$ within the $500 \mathrm{~nm}$-sections at data acquisition points. Fig. 1 also shows how values were collected in the cytosolic compartment at 0.5 and $1.0 \mu \mathrm{m}$ distance, respectively, from basal bodies.

Fig. 2 presents the calcium-specific EDX signals, i.e., the $\mathrm{Ca} \mathrm{K} \alpha$ readings obtained with wildtype cells at different times after depolarisation under "standard conditions" (see Section 2). This implies that cells were contained in a medium including $1 \mathrm{mM} \mathrm{CaCl}_{2}$ before and during stimulation by rapid mixing with $40 \mathrm{mM} \mathrm{KCl}$ to yield a final concentration of $\left[\mathrm{K}^{+}\right]=20 \mathrm{mM}$ and $\left[\mathrm{Ca}^{2+}\right]=0.5 \mathrm{mM}$, respectively. Data points indicated include bars for S.E.M. Further statistical evaluation included determination of $P$ values (see Section 2).

Remarkably, under "standard conditions", one can hardly recognise any $[\mathrm{Ca}]$ increase in cilia (with none of the $P$ values below 0.05 ) with only a very weak increase $80 \mathrm{~ms}$ after depolarisation $(P=0.21$ for $80 \mathrm{~ms}$ versus $0 \mathrm{~ms})$. Much more pronounced are $[\mathrm{Ca}]$ changes in alveolar sacs where $\mathrm{Ca} \mathrm{K} \alpha$ readings first decline $(30 \mathrm{~ms}, P=0.05)$ and then cul-
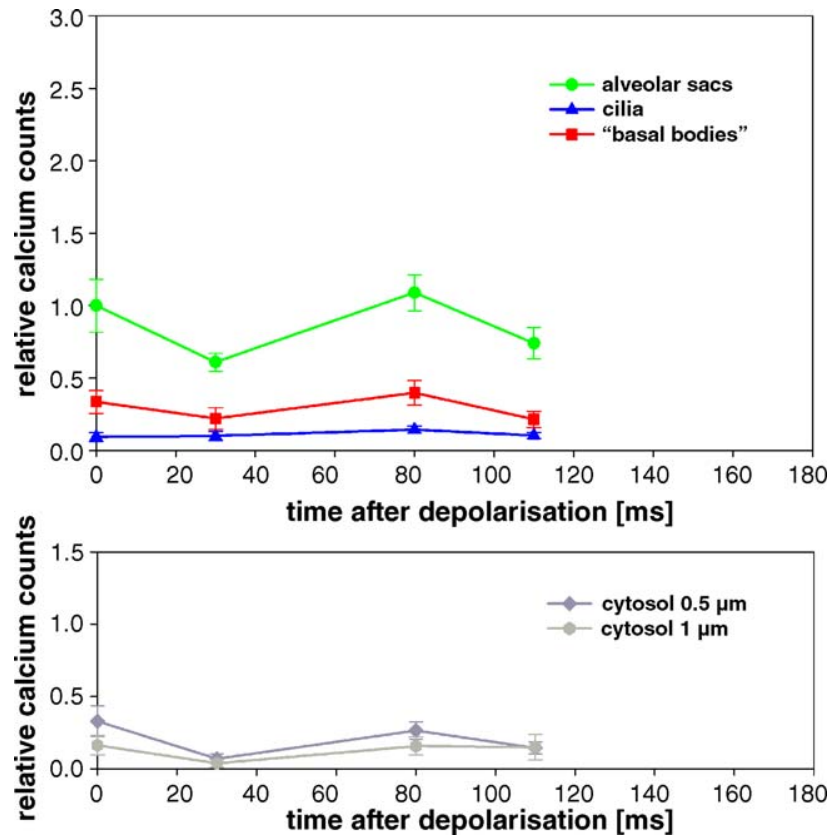

Fig. 2. Time course of $\mathrm{Ca} \mathrm{K} \alpha$ signals upon stimulation of ciliary reversal under "standard conditions". Wildtype (7S) cells (contained in $5 \mathrm{mM} \mathrm{Na}$ Pipes $+1 \mathrm{mM} \mathrm{KCl}+1 \mathrm{mM} \mathrm{CaCl}_{2}$, $\mathrm{pH} 7.2$ ) were stimulated by mixing with the same buffer and increasing $\mathrm{KCl}$ to yield $20 \mathrm{mM} \mathrm{KCl}$ (in the presence of $0.5 \mathrm{mM} \mathrm{CaCl}_{2}$ ) in the quenched-flow machine for the times indicated. All curves are normalised to $100 \%$ for $\mathrm{Ca} \mathrm{K} \alpha$ signals in alveolar sacs before stimulation. Bars $=$ S.E.M. $N$, number of cells; $n$, individual data points. For 0 s (unstimulated control), $N=10$ for all samples, $n=26,11,36,18,18$ (data sequence for alveolar sacs, basal bodies, cilia, cytoplasm 0.5 and $1.0 \mu \mathrm{m}$, respectively, below basal bodies). For $30 \mathrm{~ms}$ activation, $N=9$ for all, $n=27$, $8,35,14,13$ (same sequence). For $80 \mathrm{~ms}$ activation, $N=10$ for all, $n=33$, $13,43,18,14$ (same sequence). For $110 \mathrm{~ms}$ activation, $N=8$ for all samples, $n=19,13,43,23,17$ (same sequence as for $0 \mathrm{~s}$ [control]). No significant differences could be established by Student's $t$-test for experimental values compared to controls.

minate $80 \mathrm{~ms}$ after depolarisation $(P=0.67$ for $80 \mathrm{~ms}$ versus $0 \mathrm{~ms})$. Although much weaker, a similar tendency is recognised in "basal bodies" with their surrounding alveolar sacs. There was also some indication of $[\mathrm{Ca}]$ increase in the nearby cytosol (Fig. 2), but this also could not be statistically ascertained.

Any of the tendencies shown in Fig. 2 are much more pronounced when cells are brought into a low calcium medium, $\left[\mathrm{Ca}^{2+}\right]_{\mathrm{o}} \sim 10^{-5} \mathrm{M}$, before stimulation, followed by stimulation in the presence of $\left[\mathrm{Ca}^{2+}\right]_{\mathrm{o}}=0.5 \mathrm{mM}$ which was added only during depolarisation with $\left[\mathrm{K}^{+}\right]_{\mathrm{o}}=20 \mathrm{mM}$ for different times in the quenched-flow apparatus. Data retrieved under such "overstimulation" conditions are presented in Fig. 3. For a critical appraisal of this set-up, see Section 4.

In detail, Fig. 3 reveals a remarkable increase of $\mathrm{Ca} \mathrm{K} \alpha$ signals in cilia (values averaged from all measurements over the entire length), with a maximum $80 \mathrm{~ms}$ after depolarisation $(P<0.006$ up to 0.008 for $80 \mathrm{~ms}$ versus $30 \mathrm{~ms}, P<0.001$ up to 0.041 for $80 \mathrm{~ms}$ versus $0 \mathrm{~ms}$; ranges for $P$ values are given to compare data for the individual positions along the ciliary shaft as indicated in Fig. 1). For a trigger time $\geq 110 \mathrm{~ms}$, e.g., 

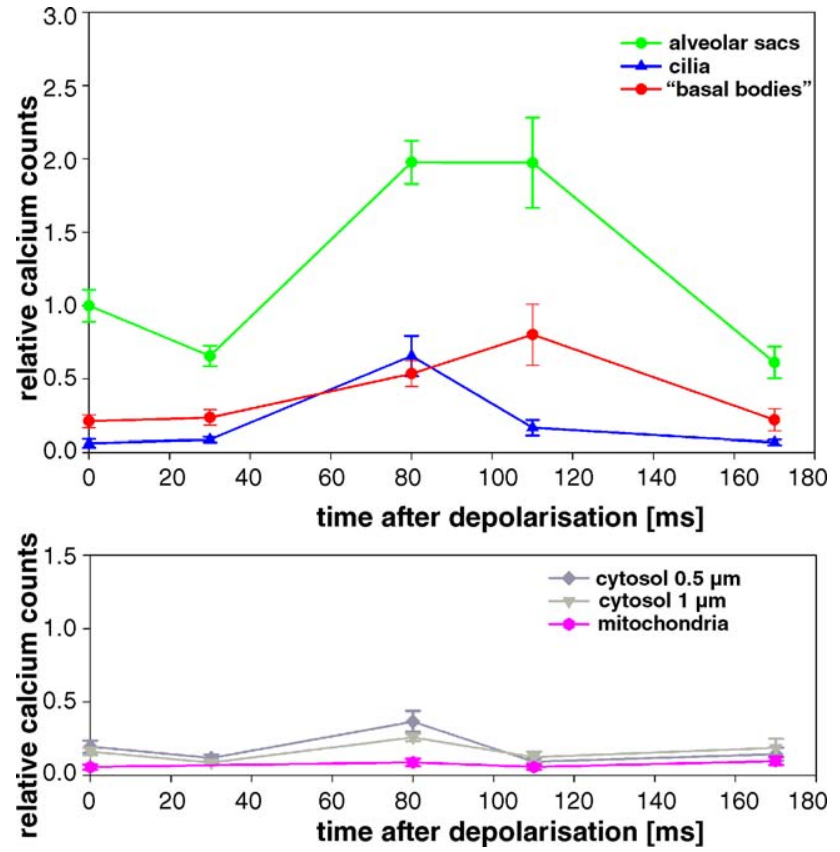

Fig. 3. Time course of $\mathrm{Ca} \mathrm{K} \alpha$ signals upon "overstimulation" of ciliary reversal. Wildtype (7S) cells (contained in $5 \mathrm{mM} \mathrm{Na}$-Pipes $+1 \mathrm{mM} \mathrm{KCl} \mathrm{[pH} \mathrm{7.2],}$ $\left[\mathrm{Ca}^{2+}\right]_{\mathrm{o}} \sim 10^{-5} \mathrm{M}$ ) were stimulated by mixing with the same solution but with $1 \mathrm{mM} \mathrm{CaCl} 2$ added only during stimulation, when $[\mathrm{KCl}]$ was increased to yield $20 \mathrm{mM}$ in the quenched-flow machine for times indicated. Controls $(0 \mathrm{~s})$ were processed without increasing $\left[\mathrm{Ca}^{2+}\right]_{\mathrm{o}}$ and $\left[\mathrm{K}^{+}\right]_{\mathrm{o}}$, respectively. All curves are normalised to $100 \%$ for $\mathrm{Ca} \mathrm{K} \alpha$ signals in alveolar sacs before stimulation. Bars $=$ S.E.M. $N$, number of cells; $n$, individual data points. For 0 s (unstimulated control), $N=27,12,155,30,30,6$ for samples in the following sequence: alveolar sacs, basal bodies; cilia, cytosol at $0.5 \mu \mathrm{m}$ from ciliary basal body, cytosol at $1.0 \mu \mathrm{m}$ from basal body, cortical mitochondria; in the same sequence, $n=38,16,257,55,55,18$. For $30 \mathrm{~ms}$ activation, in the same sequence, $N=22,12,170,29,29,0$ (mitochondria not analysed), and $n=30,13,256,41,40,0$ (mitochondria not analysed). For $80 \mathrm{~ms}$ stimulation, in the same sequence, $N=21,13,176,24,22,8$, and $n=30,13,306,43,42$, 20. For $110 \mathrm{~ms}$ activation, in the same sequence, $N=16,9,148,20,19,6$, and $n=22,9,183,25,22,27$. For $170 \mathrm{~ms}$ stimulation, in the same sequence, $N=14,6,143,19,19,6$, and $n=18,7,197,28,26,18$. For significance values, see text.

at $170 \mathrm{~ms}$ stimulation, values recorded in cilia decrease again to original levels and the values show no more any statistically significant difference $(P$ value $=0.922$ when the $170 \mathrm{~ms}$ value is referred to the $0 \mathrm{~ms}$ value). Considering the duration of one ciliary beat, i.e. $\sim 50 \mathrm{~ms},[\mathrm{Ca}]$ values recorded rise within one ciliary stroke, culminate within the second stroke and are reset to resting levels within the third stroke after depolarisation.

In Fig. 3, [Ca] values steadily increase in "basal bodies", culminating at $\sim 110 \mathrm{~ms}$, i.e., slightly after the maximum recorded in cilia $(80 \mathrm{~ms})$, before values decline. This delay is difficult to ascertain statistically, but resembles the indication of a small delay occurring in alveolar sacs (which also contribute to "basal body" data points). In alveolar sacs, values first decline slightly $(P=0.014$ for $30 \mathrm{~ms}$ versus $0 \mathrm{~ms})$, and then increase to a maximum at $\sim 95 \mathrm{~ms}$ (between 80 and $110 \mathrm{~ms}, P<0.001$ and $<0.001$, respectively, for $80 \mathrm{~ms}$ versus $0 \mathrm{~ms}$ and $110 \mathrm{~ms}$ versus $0 \mathrm{~ms}$, respectively).

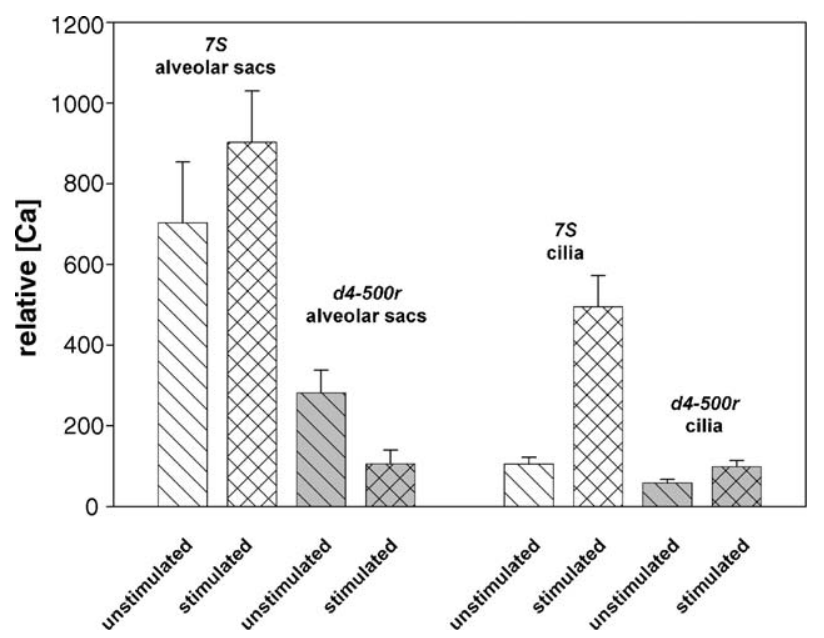

Fig. 4. Diagram showing "overstimulation" of the mutant, $d 4-500 r$ (devoid of ciliary voltage-dependent $\mathrm{Ca}^{2+}$-channels; grey blocks) under control conditions (unstimulated) and after "overstimulation" (for $7 \mathrm{~S}$ cells, see also Fig. 3) for $80 \mathrm{~ms}$. For comparison key-values obtained from wildtype cells (7S; white blocks), as reported previously [45], are included. The $d 4-500 r$ cells were exposed to conditions similar to those indicated in Fig. 2, but with $\left[\mathrm{Ca}^{2+}\right]_{\mathrm{o}}$ increased to $10 \mathrm{mM}$ (see Section 2). Bars = S.E.M. $N$, number of cells; $n$, individual data points. For $d 4-500 r$ cells, for $0 \mathrm{~s}$ (unstimulated control), $N=3$ and $n=10$ for alveolar sacs samples; $N=5, n=64$ for cilia. For $80 \mathrm{~ms}$ activation, $N=4$ and $n=8$ for alveolar sacs; $N=6, n=50$ for cilia.

Already $80 \mathrm{~ms}$ after depolarisation $\mathrm{Ca} \mathrm{K} \alpha$ counts increase in the cytosol, 0.5 and $1.0 \mu \mathrm{m}$ off basal bodies $(P=0.007$ for $0.5 \mu \mathrm{m}$ and 0.125 for $1.0 \mu \mathrm{m}$, referred to $0 \mathrm{~ms}$ values, respectively). This increase looks higher at $0.5 \mu \mathrm{m}$ distance from basal bodies than at $1.0 \mu \mathrm{m}$ distance, though this cannot be statistically ascertained $(P=0.529$ for $0.5 \mu \mathrm{m}$ versus $1.0 \mu \mathrm{m}$ distance). No increase is recognised in nearby mitochondria (Fig. 3).

In sum, the data contained in Fig. 3 would be compatible with the following sequence of events after depolarisation: influx of $\mathrm{Ca}^{2+}$ into cilia, followed by dissipation and transient uptake into nearby alveolar sacs. From there $\mathrm{Ca}^{2+}$ is dissipated into the cortical cytosol with a considerable dilution effect to levels approaching detection limit already in the outermost cytosolic layer of only a few micrometre thickness. However, this logical sequence would be difficult to ascertain from the statistics underlying the curves presented. Therefore, we resorted to the mutant lacking any functional $\mathrm{Ca}^{2+}$-channels in ciliary membranes, as it was used in the following experiments.

Using $d 4-500 r$ cells and applying "overstimulation", we have analysed [Ca] values in alveolar sacs and cilia (Fig. 4). The aim was to see how [Ca] would change in a strain which is unable to react to a depolarisation by $\mathrm{Ca}^{2+}$-influx (see Section 2 ). When compared to parallel experiments conducted with $7 S$ cells, $d 4-500 r$ cells contain much lower [Ca] in alveolar sacs and in cilia before stimulation. This is not unexpected since in different $P$. tetraurelia strains, under resting conditions, $\left[\mathrm{Ca}^{2+}\right]_{\mathrm{i}}$ may also vary to a similar extent [7], the reasons being unknown. Interestingly, during $80 \mathrm{~ms}$ stimulation, [Ca] 
values in alveolar sacs increase only in $7 S$ cells, while they decrease in $d 4-500 r$ cells, though statistically not significant $(P=0.024)$. It looks as if $d 4-500 r$ cells would maintain the depression in alveolar [Ca] seen in $7 S$ cells shortly after depolarisation (Fig. 3), the cause of this depression remaining to be settled also with the $d 4-500 r$ strain. In cilia of $d 4-500 r$ cells, [Ca] under depolarisation conditions does not change significantly, i.e., $P>0.5$ ( $80 \mathrm{~ms}$ stimulated versus unstimulated), as shown in Fig. 4. This is in clear contrast to [Ca] signals recorded in cilia of $7 S$ cells under comparable conditions of "overstimulation" (see also Fig. 3). All these findings with the $d 4-500 r$ strain are compatible with the lack of any significant $\mathrm{Ca}^{2+}$-influx into cilia and beyond, e.g., into alveolar sacs.

Mock stimulation by subjecting wildtype cells to any of the procedures outlined above, but without increasing [ $\mathrm{KCl}]$ in the medium during passage of the quenched-flow apparatus, did not cause any of the $[\mathrm{Ca}]$ changes described above for the different organelles.

\section{Discussion}

The fate of $\mathrm{Ca}^{2+}$ entering a Paramecium cell during depolarisation-induced ciliary beat reversal has not been analysed up to now. As it was routinely drawn in corresponding schemes, mainly metabolic removal by pump activities has been more or less tacitly assumed. We now show that an excess of $\mathrm{Ca}^{2+}$ after stimulation may be removed from cilia by a much more intricate mechanism, with high efficiency and speed. The elucidation of this pathway is greatly facilitated by applying conditions of "overstimulation". This does not preclude that under mild stimulation conditions $\mathrm{Ca}^{2+}$-binding to ciliary proteins may be a dominant aspect.

\subsection{Is "overstimulation" a feasible procedure?}

As outlined above, we increase the gradient between intraand extracellular $\mathrm{Ca}^{2+}$ in some of the experiments designated as "overstimulation". Although the $\left[\mathrm{Ca}^{2+}\right]_{0}$ level applied in such experiments before stimulation is low, $\sim 10^{-5} \mathrm{M}$, this is well above $\left[\mathrm{Ca}^{2+}\right]_{\mathrm{i}}$-values in unstimulated cells [7]. Since Paramecium is notoriously known as being sensitive to $\left[\mathrm{Ca}^{2+}\right]_{\mathrm{o}}=0$ [34] it should be noted that $\left[\mathrm{Ca}^{2+}\right]_{\mathrm{o}}=10^{-6} \mathrm{M}$ is well tolerated and that exocytosis - $\mathrm{a} \mathrm{Ca}^{2+}{ }_{\mathrm{o}}$-dependent process - can take place at still lower $\left[\mathrm{Ca}^{2+}\right]_{\mathrm{o}}$-values $[27,35]$. Paramecium cells rapidly react to any changes in $\left[\mathrm{Ca}^{2+}\right]_{0}$ by a change of $\left[\mathrm{Ca}^{2+}\right]_{i}$, e.g., by an increase of $\left[\mathrm{Ca}^{2+}\right]_{i}$ in parallel to an increase of $\left[\mathrm{Ca}^{2+}\right]_{\mathrm{o}}[36]$, but with no exocytotic or behavioural response in the absence of a specific stimulus [37]. This may also hold for the stores whose filling state is gradually influenced by $\left[\mathrm{Ca}^{2+}\right]_{\mathrm{o}}$, e.g., in muscle [38]. An overstimulation effect is, therefore, expected from an increase of $\left[\mathrm{Ca}^{2+}\right]_{\text {o }}$ precisely during stimulation. Thus, an increased concentration gradient can be exploited to increase the $\mathrm{Ca}^{2+}$-influx during stimulation and, hence, to increase the $[\mathrm{Ca}]$ signal to be recorded by EDX in cilia and alveolar sacs. Remarkably, the time course is similar in experiments under "overstimulation" (Fig. 3) and under "standard" conditions (Fig. 2). In sum, we are confident that "overstimulation" is a feasible way to exaggerate a physiological response which otherwise may remain much more difficult to detect.

\subsection{Comparison with electrophysiology and in vitro experiments}

In vitro, using extracted cell models, ciliary beat reversal requires only $1 \mu \mathrm{M}$ [39]. Extrapolation showed similar requirements in vivo [34]. Considering that, inside the cells, the usual ratio of total calcium, $[\mathrm{Ca}]$, to free calcium $\left[\mathrm{Ca}^{2+}\right]$, generally differs by about three to four orders of magnitude $[1,3]$, it is not surprising that we see [Ca] in cilia to rise to a level well above detectability by our EDX system, particularly during overstimulation.

Ciliary reversal starts already within one ciliary stroke, with all cilia over the entire cell surface [40]. Concomitantly, we see [Ca] to rise from $30 \mathrm{~ms}$ on and to culminate at $80 \mathrm{~ms}$, i.e., within the second stroke. Calmodulin, considered as a link between $\left[\mathrm{Ca}^{2+}\right]_{i}$ increase and ciliary reversal [41], can bind $\mathrm{Ca}^{2+}$ within milliseconds [42]. In fact, calmodulin is tightly associated with the ciliary membrane and to the axoneme [43].

From the currents measured during minimal depolarisation steps (e.g., $20 \mathrm{mV} / 4 \mathrm{~ms}$ ) at $\left[\mathrm{Ca}^{2+}\right]_{\mathrm{o}}=1 \mathrm{mM}$, the number of equivalents transferred into the estimated volume of all cilia $\left(1.7 \times 10^{-12} 1\right)$ has been estimated as $8 \times 10^{-17}$ during the time required to inactivate presumably all ciliary $\mathrm{Ca}^{2+}$ channels [16]. This would yield a $\left[\mathrm{Ca}^{2+}\right]$ of $2 \mu \mathrm{M}$ in cilia, if one disregards any further dissipation. Estimations under varied conditions were slightly above this value [15]. Assuming $80 \mathrm{~ms}$ channel activity (the time we observe [Ca] in cilia to culminate), extrapolation would result in a ciliary $\left[\mathrm{Ca}^{2+}\right]=0.08-0.16 \mathrm{mM}$ during depolarisation under conditions indicated by others $[11,44]$. Clearly such values could yield [Ca] values at the limits of detectability by our EDX recordings. Therefore, we resorted to "overstimulation" experiments. In this case, one has to consider that $[\mathrm{Ca}$ ] increases may be higher than in electrophysiological recordings. In fact, chemical depolarisation over longer times combined with ${ }^{45} \mathrm{Ca}^{2+}$ flux measurements shows much higher $\mathrm{Ca}^{2+}$ uptake since $\mathrm{Ca}^{2+}$ flux into cells (unstimulated background subtracted) lasts much longer than recorded during electrical stimulation [22]. This was explained by masked $\mathrm{Ca}^{2+}$ flux during ongoing depolarisation [13]. Concomitantly, pilot calculations from ${ }^{45} \mathrm{Ca}^{2+}$ flux data published with chemical depolarisation [22] would result in [Ca]-values approaching those we see by EDX.

Electrophysiological and EDX data are compatible if one assumes rapid $\mathrm{Ca}^{2+}$ dissipation into deeper layers or extrusion. In fact, removal of $\mathrm{Ca}^{2+}$ from cilia during 
depolarisation-induced ciliary reversal has been a postulate in electrophysiological papers $[11,12,40]$, although it was not possible experimentally to determine how this would work. Our "overstimulation" experiments show how calcium can be removed from cilia after depolarisation (at least when ciliary $\mathrm{Ca}^{2+}$-binding proteins would be saturated). The way we find is rather different from that routinely proposed in the literature, as we discuss below.

\subsection{Spread of $\mathrm{Ca} \mathrm{K} \alpha$ signals and spill-over phenomena}

We observe a rapid spread of calcium within the cilia, resulting in similar $\mathrm{Ca} \mathrm{K} \alpha$ values along the ciliary shafts. This is in conformance with other EDX analyses, showing spillover in the opposite direction, i.e., into cilia during secretion stimulation [45], and with the occurrence of ciliary reversal in $d 4-500 r$ cells during exocytosis stimulation $[45,46]$. Considering this rapid spread of $\mathrm{Ca}^{2+}$ in either direction we have averaged in our figures all data points recorded along ciliary shafts. Note that in samples designated as "basal bodies" $\sim 30 \%$ of the volume is contributed by tightly attached alveolar sacs.

How to judge $\mathrm{Ca}^{2+}$ spill-over during overstimulation? Clearly, during depolarisation, $\mathrm{Ca}^{2+}$ is not mobilised from alveolar sacs, but we find that they can take up $\mathrm{Ca}^{2+}$ very rapidly. Before stimulation, [Ca] in alveolar sacs is estimated as $43 \mathrm{mM}$ from calibrated data [29], a value well comparable with $\mathrm{Ca}^{2+}$-stores in other cells $[47,48]$. Overstimulation causes an increase in [Ca] in alveolar sacs and in the outermost cytoplasmic layer of the cell cortex. The extent of increase of $\mathrm{Ca} \mathrm{K} \alpha$ signals during overstimulation and of the shift occurring between the compartments analysed are in agreement with morphometric data [37], based on the following aspects. (i) Cilia occupy $1950 \mu \mathrm{m}^{3}$, i.e., $2.6 \%$ of the cell volume. Alveolar sacs, which can serve as an internal [Ca] standard, occupy $161 \mu^{3}$. One might estimate from Fig. 3 that during "overstimulation" [Ca] in cilia would approach values of $\sim 30 \%$ of those in alveolar sacs. If one adjusts [Ca] values in cilia ( $\sim 300 \mathrm{~nm}$ thick) for section thickness $(500 \mathrm{~nm})$, values would represent $\sim 50 \%$ of [Ca] in alveolar sacs. (ii) Considering that alveolar sacs occupy only $8.3 \%$ of the volume represented by cilia, a major fraction of $\mathrm{Ca}^{2+}$ must be rapidly dissipated, otherwise values in alveolar sacs would have to rise to much higher levels. In fact, dissipation into the cytosolic compartment must take place already within the first few ciliary beats-either directly or after passing the alveolar sacs. Since [Ca] in the sacs decays within $170 \mathrm{~ms}$ to the $[\mathrm{Ca}]$ values recorded before stimulation, most of the $\mathrm{Ca}^{2+}$ from activated cilia must finally go into the cytosol. (iii) Assuming that after "overstimulation" all $\mathrm{Ca}^{2+}$ from cilia would be dissipated into an outermost cytoplasmic layer of $2 \mu \mathrm{m}$ below alveolar sacs (the cortical layer where a detection limit of $<2 \mathrm{mM}$ is achieved), how does this compare with an estimated value of $[\mathrm{Ca}] \sim 20 \mathrm{mM}$ in cilia at the peak? Considering the ciliary volume of $2.6 \%$ of cell volume and a cell surface of $10.7 \times 10^{3} \mu \mathrm{m}^{2}$ [37], the $2 \mu \mathrm{m}$-cortex layer would represent $29 \%$ of cell volume and dilution would, therefore, reach a value of $\sim 2 \mathrm{mM}$. Since values above this detection limit value are recorded only in the outermost $1 \mu \mathrm{m}$-thick cytosolic layer, dilution must proceed rapidly to somewhat deeper layers, all within fractions of a second.

The $15 \mathrm{~nm}$ space between the cell membrane and the alveolar sacs membrane cannot be analysed by EDX. Neither one of these two membranes can be assumed to dispose of a pump appropriate for rapid $\mathrm{Ca}^{2+}$ extrusion (see below).

\subsection{Could a cation antiporter account for a rapid calcium transient in subplasmalemmal stores?}

The rapid uptake of $\mathrm{Ca}^{2+}$ into alveolar sacs, followed by rapid release that accompanies ciliary reversal, remains to be explained. A quite similar phenomenon occurs during synchronous exocytosis, also analysed by EDX [30]. Considering the slow kinetics of the SERCA-type $\mathrm{Ca}^{2+}$-pump in general [4] and in Paramecium in particular [14,28,49] this can impossibly explain the rapid $\mathrm{Ca}^{2+}$-uptake and release during overstimulation of ciliary reversal.

Remarkably, the question of coupling of stores and extracellular medium is unsettled even for rather intensely investigated cells, such as lymphocytes, for which recently Narayanan et al. [50] have postulated a direct mass-action mechanism to explain the rapid capacitative calcium entry into the ER. This would require influx channels in the cell membrane matching with juxtaposed channels in the ER membrane. However, coupling over longer distances, as seen here between cilia and alveolar sacs, may operate by a cation exchanger system. Also using EDX, a cation countertransport has indeed been found to occur in the sarcoplasmic reticulum of skeletal muscle during tetanic stimulation [51]. This may be comparable to our "overstimulation" conditions. Considering the limited knowledge on biophysical properties of $\mathrm{Ca}^{2+}$-store membranes [52] and the lack of specific antiporter inhibitors [53], our observations may contain important hints for future analyses of cortical calcium stores on a broader scale.

\section{Conclusions}

Under conditions of "overstimulation" ciliary $\mathrm{Ca}^{2+}$ binding proteins may be unable to bind all of the $\mathrm{Ca}^{2+}$-influx. High $\left[\mathrm{Ca}^{2+}\right]$ in cilia may then cause rapid influx into the nearby alveolar sacs in which $\left[\mathrm{Ca}^{2+}\right]$, even at high lumenal $[\mathrm{Ca}]$, is probably sufficiently low due to high capacity/low affinity $\mathrm{Ca}^{2+}$-binding proteins [54], as expected from observations with other systems [48]. Further dissipation would follow the gradient toward deeper cytosolic layers. Since $\mathrm{Ca}^{2+}$-pumps are much too slow it seems reasonable to assume a rapidly acting antiporter system for the processes we describe here. This combined "vacuum cleaner/shower" function can avoid too high local $\left[\mathrm{Ca}^{2+}\right]$ over longer times which could be deleterious to the cells. 


\section{Acknowledgements}

This work has been supported by grants from the Deutsche Forschungsgemeinschaft to H.P.

\section{References}

[1] M.J. Berridge, M.D. Bootman, H.L. Roderick, Calcium signalling: dynamics, homeostasis and remodelling, Nat. Rev. Mol. Cell Biol. 4 (2003) 517-529.

[2] O.H. Petersen, M. Michalak, A. Verkhratsky, Calcium signalling: past, present and future, Cell Calcium 38 (2005) 161-169.

[3] A. Verkhratsky, Physiology and pathophysiology of the calcium store in the endoplasmic reticulum of neurons, Physiol. Rev. 85 (2005) 201-279.

[4] D. Guerini, L. Coletto, E. Carafoli, Exporting calcium from cells, Cell Calcium 38 (2005) 281-289.

[5] F. Michelangeli, O.A. Ogunbayo, L.L. Wootton, A plethora of interacting organellar $\mathrm{Ca}^{2+}$ stores, Curr. Opin. Cell Biol. 17 (2005) $135-140$.

[6] C. Montell, The latest waves in calcium signaling, Cell 122 (2005) $157-163$

[7] N. Klauke, H. Plattner, Imaging of $\mathrm{Ca}^{2+}$ transients induced in Paramecium cells by a polyamine secretagogue, J. Cell Sci. 110 (1997) 975-983

[8] N. Klauke, M.-P. Blanchard, H. Plattner, Polyamine triggering of exocytosis in Paramecium involves an extracellular $\mathrm{Ca}^{2+} /($ polyvalent cation)-sensing receptor, subplasmalemmal Ca-store mobilization and store-operated $\mathrm{Ca}^{2+}$-influx via unspecific cation channels, J. Membr. Biol. 174 (2000) 141-156.

[9] H. Machemer, Electrophysiology, in: H.D. Görtz (Ed.), Paramecium, Springer-Verlag, Berlin, Heidelberg, 1988, pp. 185-215.

[10] H. Machemer, Motor control of cilia, in: H.D. Görtz (Ed.), Paramecium, Springer-Verlag, Berlin, Heidelberg, 1988, pp. 216-235.

[11] R. Eckert, P. Brehm, Ionic mechanisms of excitation in Paramecium, Annu. Rev. Biophys. Bioeng. 8 (1979) 353-383.

[12] R. Eckert, Bioelectric control of ciliary activity, Science 176 (1972) 473-481.

[13] R. Eckert, Genes, channels and membrane currents in Paramecium, Nature 268 (1977) 104-105.

[14] H. Plattner, N. Klauke, Calcium in ciliated protozoa: sources, regulation, and calcium regulated functions, Int. Rev. Cytol. 201 (2001) 115-208.

[15] P. Brehm, R. Eckert, Calcium entry leads to inactivation of calcium channel in Paramecium, Science 202 (1978) 1203-1206.

[16] D. Oertel, S.J. Schein, C. Kung, Separation of membrane currents using a Paramecium mutant, Nature 268 (1977) 120-124.

[17] I.B. Levitan, It is calmodulin after all! Mediator of the calcium modulation of multiple ion channels, Neuron 22 (1999) 645-648.

[18] B.Z. Peterson, C.D. De Maria, D.T. Yue, Calmodulin is the $\mathrm{Ca}^{2+}$ sensor for $\mathrm{Ca}^{2+}$-dependent inactivation of L-type calcium channels, Neuron 22 (1999) 549-558.

[19] M. Morad, N. Soldatov, Calcium channel inactivation: possible role in signal transduction and $\mathrm{Ca}^{2+}$ signaling, Cell Calcium 38 (2005) 223-231.

[20] H. Machemer, A. Ogura, Ionic conductances of membranes in ciliated and deciliated Paramecium, J. Physiol. 296 (1979) 49-60.

[21] Y. Saimi, C. Kung, Calmodulin as an ion channel subunit, Annu. Rev. Physiol. 64 (2002) 289-311.

[22] J.L. Browning, D.L. Nelson, H.G. Hansma, $\mathrm{Ca}^{2+}$ influx across the excitable membrane of behavioural mutants of Paramecium, Nature 259 (1976) 491-494.

[23] M.V. Wright, N. Elwess, J. Van Houten, $\mathrm{Ca}^{2+}$ transport and chemoreception in Paramecium, J. Comp. Physiol. B 163 (1993) 288-296.
[24] K. Hauser, N. Pavlovic, R. Kissmehl, H. Plattner, Molecular characterization of a sarco(endo)plasmic reticulum $\mathrm{Ca}^{2+}$-ATPase gene from Paramecium tetraurelia and localization of its gene product to sub-plasmalemmal calcium stores, Biochem. J. 334 (1998) 3138.

[25] H. Plattner, M. Flötenmeyer, R. Kissmehl, N. Pavlovic, K. Hauser, M. Momayezi, N. Braun, J. Tack, L. Bachmann, Microdomain arrangement of the SERCA-type $\mathrm{Ca}^{2+}$ pump $\left(\mathrm{Ca}^{2+}\right.$-ATPase $)$ in subplasmalemmal calcium stores of Paramecium cells, J. Histochem. Cytochem. 47 (1999) 841-853.

[26] N. Stelly, J.P. Mauger, G. Keryer, M. Claret, A. Adoutte, Cortical alveoli of Paramecium: a vast submembranous calcium storage compartment, J. Cell Biol. 113 (1991) 103-112.

[27] G. Knoll, A. Grässle, C. Braun, W. Probst, B. Höhne-Zell, H. Plattner, A calcium influx is neither strictly associated with nor necessary for exocytotic membrane fusion in Paramecium cells, Cell Calcium 14 (1993) 173-183.

[28] S. Länge, N. Klauke, H. Plattner, Subplasmalemmal $\mathrm{Ca}^{2+}$ stores of probable relevance for exocytosis in Paramecium. Alveolar sacs share some but not all characteristics with sarcoplasmic reticulum, Cell Calcium 17 (1995) 335-344.

[29] M. Hardt, H. Plattner, Quantitative energy-dispersive X-ray microanalysis of calcium dynamics in cell suspensions during stimulation on a subsecond time scale: preparative and analytical aspects as exemplified with Paramecium cells, J. Struct. Biol. 128 (1999) 187-199.

[30] M. Hardt, H. Plattner, Sub-second quenched-flow/X-ray microanalysis shows rapid $\mathrm{Ca}^{2+}$ mobilization from cortical stores paralleled by $\mathrm{Ca}^{2+}$ influx during synchronous exocytosis in Paramecium cells, Eur. J. Cell Biol. 79 (2000) 642-652.

[31] G. Knoll, C. Braun, H. Plattner, Quenched flow analysis of exocytosis in Paramecium cells: time course, changes in membrane structure, and calcium requirements revealed after rapid mixing and rapid freezing of intact cells, J. Cell Biol. 113 (1991) 12951304.

[32] N. Haga, M. Forte, Y. Saimi, C. Kung, Microinjection of cytoplasm as a test of complementation in Paramecium, J. Cell Biol. 92 (1982) $559-564$.

[33] M.K. Park, O.H. Petersen, A.V. Tepikin, The endoplasmic reticulum as one continuous $\mathrm{Ca}^{2+}$ pool: visualization of rapid $\mathrm{Ca}^{2+}$ movements and equilibration, EMBO J. 19 (2000) 5729-5739.

[34] R. Eckert, Y. Naitoh, H. Machemer, Calcium in the bioelectric and motor functions of Paramecium, in: C.J. Duncam (Ed.), Calcium in Biological Systems, Soc. Exptl. Biol., Cambridge, 1976, pp. 233-255.

[35] D. Kerboeuf, J. Cohen, A $\mathrm{Ca}^{2+}$ influx associated with exocytosis is specifically abolished in a Paramecium exocytotic mutant, J. Cell Biol. 111 (1990) 2527-2535.

[36] J.L. Browning, D.L. Nelson, Biochemical studies of the excitable membrane of Paramecium aurelia. I. ${ }^{45} \mathrm{Ca}^{2+}$ fluxes across resting and excited membrane, Biochim. Biophys. Acta 448 (1976) 338-351.

[37] C. Erxleben, N. Klauke, M. Flötenmeyer, M.-P. Blanchard, C. Braun, H. Plattner, Microdomain $\mathrm{Ca}^{2+}$ activation during exocytosis in Paramecium cells. Superposition of local subplasmalemmal calcium store activation by local $\mathrm{Ca}^{2+}$ influx, J. Cell Biol. 136 (1997) 597-607.

[38] J.W. Kramer, A.M. Corbett, Comparison of $\mathrm{Ca}^{2+}$ loading and retention in isolated skeletal muscle triads and terminal cisternae, Am. J. Physiol. Cell Physiol. 270 (1996) C1602-C1610.

[39] Y. Naitoh, H. Kaneko, Reactivated Triton-extracted models of Paramecium: modification of ciliary movement by calcium ions, Science 176 (1972) 523-524.

[40] H. Machemer, Electromotor coupling in cilia, Fortschr. Zool. 33 (1986) 205-250.

[41] H. Machemer, P.F.M. Teunis, Sensory-motor coupling and motor responses, in: K. Hausmann, P.C. Bradbury (Eds.), Ciliates. Cells and Organisms, Gustav Fischer Verlag, Stuttgart, 1996, pp. 379-402. 
[42] J.P. Davis, S.B. Tikunova, M.P. Walsh, J.D. Johnson, Characterizing the response of calcium signal transducers to general calcium transients, Biochemistry 38 (1999) 4235-4244.

[43] M. Momayezi, H. Kersken, U. Gras, J. Vilmart-Seuwen, H. Plattner, Calmodulin in Paramecium tetraurelia: localization from the in vivo to the ultrastructural level, J. Histochem. Cytochem. 34 (1986) 1621-1638.

[44] H. Machemer, Modification of ciliary activity by the rate of membrane potential changes in Paramecium, J. Comp. Physiol. 101 (1975) 343-356.

[45] M.R. Husser, M. Hardt, M.-P. Blanchard, J. Hentschel, N. Klauke, H. Plattner, One-way calcium spill-over during signal transduction in Paramecium cells: from the cell cortex into cilia, but not in the reverse direction, Cell Calcium 36 (2004) 349-358.

[46] H. Plattner, H. Matt, H. Kersken, B. Haacke, R. Stürzl, Synchronous exocytosis in Paramecium cells. VI. A novel approach, Exp. Cell Res. 151 (1984) 6-13.

[47] A.V. Somlyo, M. Bond, H. Shuman, A.P. Somlyo, Electron-probe $\mathrm{X}$ ray microanalysis of in situ calcium and other ion movements in muscle and liver, Ann. N.Y. Acad. Sci. 483 (1986) 229-240.

[48] J. Meldolesi, T. Pozzan, The endoplasmic reticulum $\mathrm{Ca}^{2+}$ store: a view from the lumen, Trends Biochem. Sci. 23 (1998) 10-14.
[49] I. Mohamed, M. Husser, I. Sehring, J. Hentschel, H. Plattner, Refilling of cortical calcium stores in Paramecium cells: in situ analysis in correlation with store-operated calcium influx, Cell Calcium 34 (2003) 87-96.

[50] B. Narayanan, M.N. Islam, D. Bartelt, R.S. Ochs, A direct mass-action mechanism explains capacitative calcium entry in Jurkat and skeletal L6 muscle cells, J. Biol. Chem. 278 (2003) 44188-44196.

[51] A.V. Somlyo, H. Gonzalez-Serratos, H. Shuman, G. McCellan, A.P. Somlyo, Calcium release and ionic changes in the sarcoplasmic reticulum of tetanized muscle: an electron-probe study, J. Cell Biol. 90 (1981) 577-594

[52] D. Burdakov, O.H. Petersen, A. Verkhratsky, Intraluminal calcium as a primary regulator of endoplasmic reticulum function, Cell Calcium 38 (2005) 303-310.

[53] L. Annunziato, G. Pignataro, G.F. Di Renzo, Pharmacology of brain $\mathrm{Na}^{+} / \mathrm{Ca}^{2+}$ exchanger: from molecular biology to therapeutic perspectives, Pharmacol. Rev. 56 (2004) 633-654.

[54] H. Plattner, A. Habermann, R. Kissmehl, N. Klauke, I. Majoul, H.D. Söling, Differential distribution of calcium stores in Paramecium cells. Occurrence of a subplasmalemmal store with a calsequestrinlike protein, Eur. J. Cell Biol. 72 (1997) 297-306. 